\author{
L.F. Il'ina, A.A. Kharissova \\ Ye.A. Buketov Karaganda State University, Kazakhstan \\ (E-mail:aigerim_tana@mail.ru)
}

\title{
Designing of the multimedia presentations on the example of the section: «Mechanical oscillations and waves» and their use in high school and school courses of physics
}

\begin{abstract}
In teaching physics, as well as in teaching other subjects, various methods of training have to be applied. At the choice of these or those methods of training it is necessary to consider, first of all, character of the educational tasks solved at a lesson, age features of the studying senior classes, students their aspiration to independent judgments, the level of the informative abilities which are available for them. In the article multimedia presentations are considered on the example of the section: «Mechanical oscillations and waves» and their use in university and school physics courses. The relevance of the article is the need to develop a methodology for presenting the topic so that it can be used to implement both basic and specialized education in the school and at the university in the course of general physics. The theory of the question is briefly stated. Kinematic and dynamic analyzes of the oscillatory process are presented. The features of the content of this topic are analyzed in the university course of physics.
\end{abstract}

Keywords: mechanical oscillations and waves, harmonic oscillations, physical and mathematical pendulum.

Oscillations are called movements or processes which are characterized by a certain recurrence in time. Oscillatory processes are widespread in the nature and technique, for example rolling of a pendulum of hours, an alternating electric current and so on. In case of an oscillating motion of a pendulum the coordinate of its center of masses changes, in case of an alternating current tension and a circuit current fluctuate. The physical nature of oscillations can be different therefore mechanical, electromagnetic and others distinguish oscillations. However various oscillatory processes are described by identical characteristics and the identical equations. From here expediency of uniform approach to studying of fluctuations of various physical natures follows. For example, uniform approach to studying of mechanical and electromagnetic oscillations was applied by the English physicist D. Rayleigh (1842-1919), A.G. Stoletovy, Russian engineer, P.N. Lebedev (1866-1912). The big contribution to development of the theory of fluctuations was made by the Soviet physicist L.I. Mandelstam (1879-1944) and his pupils.

Fluctuations are called free (or own) if they are made due to originally reported energy at the subsequent absence external impact on oscillatory system (the system making fluctuations). The simplest type of fluctuations is harmonic oscillations - fluctuations in case of which the fluctuating size changes under the law of a sine (cos) over time. Consideration of harmonic oscillations is important for two reasons: 1) the fluctuations which are found in the nature and equipment often have the character close to harmonic; 2) various periodic processes (the processes repeating at regular intervals) can be presented as imposing of harmonic oscillations. Harmonic oscillations of size $x$ are described by the type equation

$$
x=A \cos \left(\omega_{0} t+\varphi\right),
$$

where $A$ - the maximum offset of the fluctuating material point called by vibration amplitude; $\omega_{0}$ - circular (cyclic) frequency; $\varphi$ - initial phase of fluctuations; $\left(\omega_{0} t+\varphi\right)-$ phase of fluctuations in a timepoint $t$. As the cosine changes ranging from +1 to -1 , that $x$ can accept values from $+\mathrm{A}$ to $-\mathrm{A}$.

Certain conditions of the system making harmonic oscillations repeat through a period $T$ called by the fluctuation period for which the phase of fluctuation receives an increment $2 \pi$, that is

$$
\omega_{0}(t+T)+\varphi=\left(\omega_{0} t+\varphi\right)+2 \pi
$$

from here

$$
T=\frac{2 \pi}{\omega_{0}} .
$$

Size, the return to the period of fluctuations,

$$
\mathrm{v}=\frac{1}{T},
$$


that is the number of the full waves made in unit of time is called oscillation frequency. Comparing (2) and (3), we will receive

$$
\omega_{0}=2 \pi v .
$$

Frequency unit — hertz $(\mathrm{Hz}): 1 \mathrm{~Hz}$ - frequency of periodic process in case of which for $1 \mathrm{~s}$ one oscillations is made.

We will call the speed and acceleration of the fluctuating material point:

$$
\begin{aligned}
& \frac{d x}{d t}=-A \omega_{0} \sin \left(\omega_{0} t+\varphi\right)=A \omega_{0} \cos \left(\omega_{0} t+\varphi+\frac{\pi}{2}\right) ; \\
& \frac{d^{2} x}{d t^{2}}=-A \omega_{0}^{2} \cos \left(\omega_{0} t+\varphi\right)=A \omega_{0}^{2} \cos \left(\omega_{0} t+\varphi+\pi\right)
\end{aligned}
$$

that is they change under the harmonious law with the same cyclic frequency. Amplitudes of sizes (4) and (5) are respectively equal $A \omega_{0}$ and $A \omega_{0}^{2}$. Speed phase (4) differs from a size phase (1) on $\pi / 2$. Therefore, in time points, when $x=0, \frac{d x}{d t}$ gains the greatest values; when $x$ reaches the maximum negative value, that $\frac{d^{2} x}{d t^{2}}$ gains the greatest positive value [1-3].

Harmonic oscillations are kinematic analyzed by means of a method of the rotating amplitude vector, or a method of vector charts. For this purpose from any point $O$, chosen on an axis $x$, at angle $\varphi$, equal to an initial phase of fluctuation, the vector is postponed $\vec{A}$, which module is equal to amplitude $A$ the considered fluctuation (Fig. 1). If to bring this vector into rotation with an angular speed $\omega_{0}$, that the projection of the end of a vector will move on an axis $x$ and to accept values from $-\vec{A}$ to $+\vec{A}$, and the fluctuating size will change under the law over time $x=A \cos \left(\omega_{0} t+\varphi\right)$. Thus, harmonic oscillation can be presented a projection to some randomly the chosen amplitude vector axis A, postponed from any point of an axis at an angle $\varphi$, equal to an initial phase, and rotating with an angular speed $\omega_{0}$ around this point.

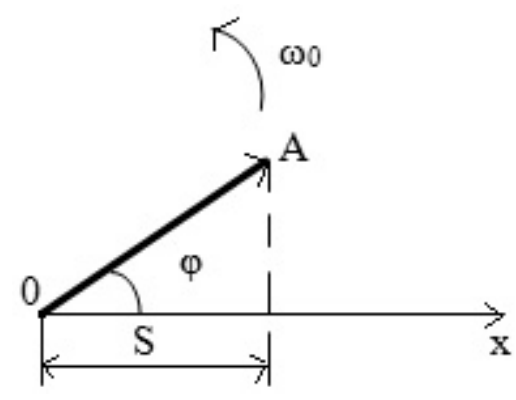

Figure 1. Harmonic oscillation in the form of a projection

In physics other method which differs from a method of the rotating amplitude vector only on mathematical design is often applied. In this method offset of the material point is represented a complex number. According to Euler's formula, for complex numbers

$$
e^{i \alpha}=\cos \alpha+i \sin \alpha,
$$

where $i=\sqrt{-1}$ - imaginary unit. Therefore equation of harmonious fluctuation (1) it is possible to write down in an exponential form:

Material part of expression (7)

$$
\tilde{x}=A e^{i\left(w_{0} t+\varphi\right)} .
$$

$$
\operatorname{Re}(\tilde{x})=A \cos \left(\omega_{0} t+\varphi\right)=x
$$

describes harmonic oscillation. The designation Re of material part further we will agree to lower and (7) we will write down in a look

$$
x=A e^{i\left(\omega_{0} t+\phi\right)} .
$$

In the theory of fluctuations is accepted that shift $x$ equally material part of the complex expression standing in this equality on the right. 
Let the material point make rectilinear harmonic oscillations along an axis $\mathrm{x}$ about position of the balance taken for the beginning of coordinates. Then dependence of coordinate $\mathrm{x}$ on time of $\mathrm{t}$ is set by the equation similar to the equation (1):

$$
x=A \cos \left(\omega_{0} t+\varphi\right) .
$$
equal

According to expressions (4) and (5), speed $v$ and acceleration $a$ the fluctuating point respectively are

$$
\begin{gathered}
v=-A \omega_{0} \sin \left(\omega_{0} t+\varphi\right)=A \omega_{0} \cos \left(\omega_{0} t+\varphi+\pi / 2\right) \\
a=-A \omega_{0}^{2} \cos \left(\omega_{0} t+\varphi\right)=A \omega_{0}^{2} \cos \left(\omega_{0} t+\varphi+\pi\right) .
\end{gathered}
$$

The force $F=m a$, acting on the fluctuating material point with weight $m$, taking into account (8) and (9) equal to

$$
F=-m \omega_{0}^{2} x
$$

Therefore, force is proportional to the shift of a material point from position of balance and is sent to the opposite side (to balance position) $[4,5]$.

Kinetic energy of the material point making rectilinear harmonic oscillations is equal.

$$
T=\frac{m v^{2}}{2}=\frac{m A^{2} \omega_{0}^{2}}{2} \sin ^{2}\left(\omega_{0} t+\varphi\right)
$$

Potential energy of the material point making harmonic oscillations under the influence of the elastic force of $\mathrm{F}$ is equal

$$
\Pi=-\int_{0}^{x} F d x=\frac{m \omega_{0}^{2} x^{2}}{2}=\frac{m A^{2} \omega_{0}^{2}}{2} \cos ^{2}\left(\omega_{0} t+\varphi\right) .
$$

Having put (10) and (11), we will receive a formula for a total energy:

$$
E=T+\Pi=m A^{2} \omega_{0}^{2} / 2 .
$$

The total energy remains to a constant as in case of harmonic oscillations conservation law of mechanical energy as elastic force is conservative is fair.

Harmonic oscillator is called the system making the fluctuations described by the look equation:

$$
\ddot{x}+\omega_{0}^{2} x=0 .
$$

Fluctuations of a harmonic oscillator are an important example of a periodic example of the movement and serve as exact or approximate model in many problems of classical and quantum physics. So a harmonic oscillator is spring, physical and mathematical pendulums, an oscillatory contour (for currents and tension so small that elements of a contour could be considered linear).

The spring pendulum is the freight the mass of $\mathrm{m}$ suspended on absolutely elastic spring, making harmonic oscillations under the influence of elastic force: $F=-k x$, where $k$ - the elasticity coefficient in case of a spring called by rigidity. Equation of the movement of a pendulum

$$
m \ddot{x}=-k x \text { or } \ddot{x}+\frac{k}{m} x=0 .
$$

From expressions (13) and (1) follows that the spring pendulum makes harmonic oscillations under the law $x=A \cos \left(\omega_{0} t+\varphi\right)$ with a cyclic frequency

and period

$$
\omega_{0}=\sqrt{k / m}
$$

$$
T=2 \pi \sqrt{m / k} .
$$

The formula (15) it is fair for elastic fluctuations in limits in which Hooke's law that is when the mass of a spring is small in comparison with body weight is carried out.

Potential energy of a spring pendulum is equal:

$$
\Pi=k x^{2} / 2 \text {. }
$$

The physical pendulum is the solid body making by gravity fluctuations around the motionless horizontal axis of a suspension which isn't passing through the center of masses $C$ a body [6].

The mathematical pendulum is the idealized system consisting of a material point the mass of $\mathrm{m}$ suspended on an inextensible weightless thread, and fluctuating by gravity. Good approach of a mathematical pendulum is the small heavy ball suspended on a thin long thread [7-9]. 
Moment of inertia of a mathematical pendulum

$$
J=m \ell^{2},
$$

where $\ell$ - pendulum length.

As the mathematical pendulum can be presented as a special case of a physical pendulum, having assumed that all his weight is concentrated in one point - the center of masses, having substituted expression (16) in the formula $T=2 \pi / \omega_{0}=2 \pi \sqrt{\frac{J}{(m g \ell)}}=2 \pi \sqrt{\frac{\ell}{g}}$, we will receive expression for the period of small fluctuations of a mathematical pendulum

$$
T=2 \pi \sqrt{\ell / g} \text {. }
$$

Due to the increase of scientific-theoretical level of a course of physics at high school increasing it is given to the solution of physical tasks.

It is aware physics of high school to overestimate educational, polytechnic and educational value of tasks difficult. Without solution of physical tasks, the course of physics can't be acquired. At the majority of schools the considerable attention is paid to the solution of physical tasks. Nevertheless, many pupils constantly experience difficulties in the solution of tasks that visually it is found at final and school examinations, and at entrance examinations in higher education institutions. It speaks not only complexity of this type of occupations for pupils, but also shortcomings of selection and a technique of the solution of tasks of a school course of physics.

Questions of a technique of the solution of tasks on physics at high school are of particular importance now. An effective objective teachers allow to acquaint with the most general acceptances and methods of the solution of standard tasks which create physical thinking of pupils to them the corresponding practical skills [10].

The solution of tasks is the integral component of educational process because allows to form and enrich physical concepts, develops physical thinking of pupils, their skills of application of knowledge in practice. In the course of the solution of tasks diligence, inquisitiveness of mind, independence in judgments are formed, interest in study is cultivated, the will and character becomes tempered, ability to analyze the phenomena, to generalize the information about them and so forth develops. A big role of tasks in implementation of the polytechnic principle of training. The solution of tasks is way of check and systematization of knowledge, gives the chance to rationally carry out repetition, to expand and deepen knowledge, promotes formation of outlook, acquaints with achievements of science, equipment to that other.

We will consider as examples of a problem of the increased complexity (high school tasks).

№ 1

In Earth the direct tunnel which isn't passing through her center is dug. Determine time of the movement of the train with the switched-off engines by such tunnel if to neglect influence of rotation of Earth on the movement of the train and friction $[11 ; 97]$.

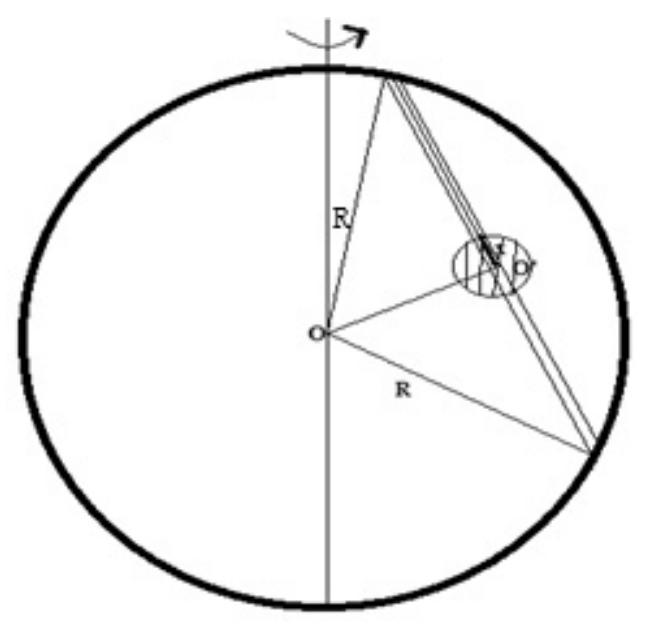

Figure 2. The tunnel dug in Earth

Draw the Earth's radius $R$ to the beginning and end of the tunnel. We obtain an isosceles triangle. From its top drop a perpendicular to the base, which is the median and bisector? Consider a body at a distance $x$ from the base of the perpendicular $O^{\prime}$ and the law of universal gravitation determine the force exerted on the body by a sphere of radius $x$.

$$
F=\gamma \frac{m M(x)}{x^{2}}
$$

We find the mass of the ball:

$$
M(x)=\rho \frac{4}{3} \pi x^{3},
$$

where $\rho$ Earth's density.

$$
F=\gamma \frac{m \cdot \rho \frac{4}{3} \pi x^{2}}{x^{2}}=\frac{4}{3} \pi \gamma m \rho x .
$$

It is easy to see that this is a quasi-elastic force; that is the nature of body movements - vibration. 
It is known that

$$
k=m \omega^{2},
$$

where $\omega-$ cyclic frequency $\omega=\sqrt{\frac{k}{m}}=\frac{2 \pi}{T}$ factor is: $k=\frac{4}{3} \pi \gamma m \rho$.

Go to the period. Interest to us time $\tau=\frac{T}{2}$.

№ 2

The particle makes harmonic oscillations along an axis $x$ under the law $x=a \cos \omega t$. Considering, probability $W$ of finding of a particle in an interval from $-a$ to $+a$ equal to 1 , to find dependence from $x$ probability density $d W / d x$, where $d W$ - probability of finding of a particle in an interval from $x$ to $x+d x$. To represent the schedule $d W / d x$ depending on $x[12 ; 97]$.

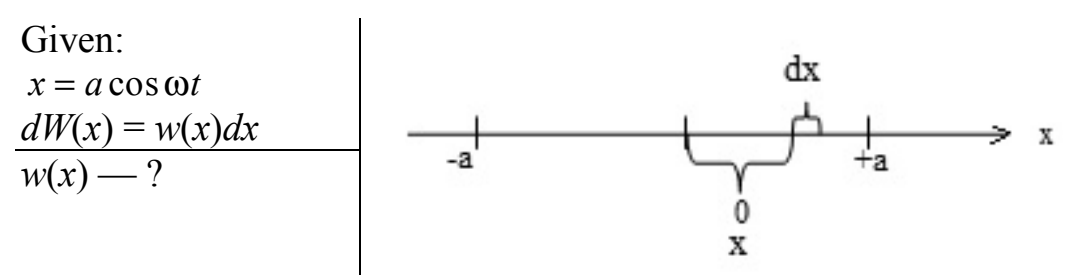

$d W(x)$ - probability of finding of the fluctuating particle in the range from $x$ to $x+d x ; w(x)$ - probability density.

Temporary definition:

$$
d W(x)=\frac{d t}{\frac{T}{2}}
$$

where $d t$ - the particle time spent in the specified interval, $T$ - period.

$$
d W(x)=\frac{d t}{\frac{T}{2}}=w(x) d x .
$$

From here

$$
w(x)=\frac{2}{T \frac{d x}{d t}}=\frac{2}{T \nu}=\frac{2}{\frac{2 \pi}{\omega} a \omega \sin \omega t}=\frac{1}{\pi a \sin \omega t}=\frac{1}{\pi a \sqrt{1-\cos ^{2} \omega t}}=\frac{1}{\pi \sqrt{a^{2}-x^{2}}},
$$

so, $w(x)=\frac{1}{\pi \sqrt{a^{2}-x^{2}}}$.

№ 3

Liquid volume $V=16 \mathrm{~cm}^{3}$ it is poured in curved U-figurative tube with the cross-sectional area of the channel $\mathrm{S}=0,50 \mathrm{~cm}^{2}$. Neglecting viscosity, to find the period of small fluctuations of liquid $[13 ; 23]$.

$$
\begin{aligned}
& \text { Given: } \\
& V=16 \mathrm{~cm}^{3}=1,6 \cdot 10^{-5} \mathrm{M}^{3} \\
& \text { U-tube } \\
& S=0,5 \mathrm{~cm}^{2}=0,5 \cdot 10^{-4} \mathrm{M}^{2} \\
& \eta->0 \\
& \hline T=?
\end{aligned}
$$
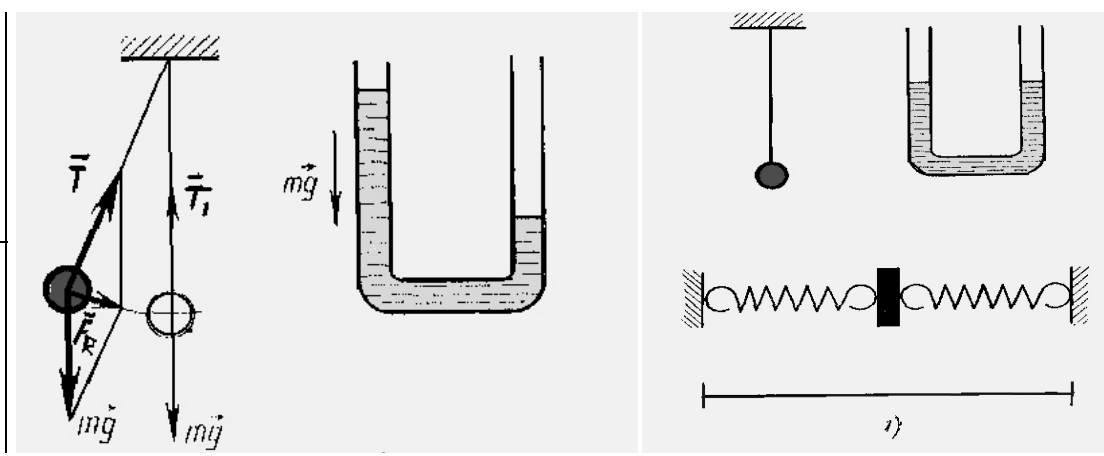

1)

Fluctuations are caused by quasi-elastic force (at the expense of gravity), as at a mathematical pendulum. On a condition they — not fading.

$$
T=2 \pi \sqrt{\frac{l}{2 g}}
$$


where $\frac{l}{2}$ — plays a role «pendulum lengths»; $V=l \cdot S ; l=\frac{V}{S} ; T=\pi \sqrt{\frac{2 V}{S \cdot g}}$.

We consider: $T \cong 0.8 \mathrm{c}$.

It is known that the pedagogical technology is an answer to the question «how to learn?». There are technologies of training, education, social and educational and only about 500 educational technologies. Thus pedagogical technology — the phenomenon multidimensional [14-16].

In February, 2016 on a subject pedagogical experiment in Nazarbayev intellectual school of the city Karaganda in the 9 th class has been made.

It included formativny estimation and independent work.

For check of level of digestion of material on a subject by students the Hag of Ye.A.Buketova have carried out a physical dictation and trial testing.

Results are analyzed.

Thus, results of training of pupils and students on the subject «Mechanical Oscillations and Waves» are presented in the offered article, starting with the analysis of theoretical material, selection of problems of the increased complexity with use of the multimedia presentations finishing with an assessment of level of digestion of material by them.

In conclusion we will note the following: use of interactive technologies, in particular the multimedia presentations, allows to select, analyze and illustrate competently theoretical material on any subject; to facilitate the solution of problems of the increased complexity that it is especially important when studying such difficult subjects as «Mechanical oscillations and waves» especially as the first task, for example, connects on the one hand, gravitational interactions, and about other, oscillatory process; the second task is very unusual according to the contents - is devoted to a linear harmonic oscillator, and it is necessary to find probability of finding of the fluctuating material point in an elementary interval of coordinates, and it is purely statistical task from molecular physics.

\section{References}

1 Безрукова В.С. Всё о современном уроке в школе: проблемы и решения / В.С. Безрукова. - М.: Сентябрь, 2004. $306 \mathrm{c}$.

2 Гребенкина Т.М. Физика. 7 класс. Нестандартные уроки / Т.М. Гребенкина. — Волгоград: ИТД «Корифей», 2005. $250 \mathrm{c}$.

3 Мастропас 3.П. Физика: Методика и практика преподавания / Мастропас 3.П., Синдеев Ю.Г. — Ростов н/Д.: Феникс, 2002. - $308 \mathrm{c}$.

4 Фриш С.Э. Курс общей физики. Т. 1. Физические основы механики. Молекулярная физика. Колебания и волны / С.Э. Фриш, А.В. Тиморева. - М.: ГИФМЛ, 1962. — 230 с.

5 Обморшев А.Н. Введение в теорию колебаний / А.Н. Обморшев. - М.: Наука, 1965. — 165 с.

6 [Электронный pecypc]. Режим доступа: http://eqworld.ipmnet.ru/ru/library.htm

7 [Электронный ресурс]. Режим доступа: http://flash-fizika.narod.ru/physic.doc.com

8 Александров Н.В. Курс общей физики. Механика / Н.В. Александров, А.Я. Яшкин. - М.: Просвещение, 1978. $440 \mathrm{c}$.

9 Черноуцан А.И. Краткий курс физики / А.И. Черноуцан. - М.: Физматлит, 2002. — 503 с.

10 Орир Дж. Физика. Т. 1 / Дж. Орир. - М.: Мир, 1981. - 336 с.

11 Иродов И.Е. Задачи по общей физике / И.Е. Иродов. - М.: Наука, 1988. - 503 с.

12 Степанова Г.Н. Сборник вопросов и задач по физике. Для 10-11 классов общеобразовательной школы / Г.Н.Степанова. - СПб.: Спец. лит., 1997. - 384 с.

13 Балаш В.А. Задачи по физике и методы их решения / В.А. Балаш. - М.: Просвещение, 1974. — 448 с.

14 [Электронный ресурс]. Режим доступа: http://www.metod-kopilka.ru/formativnoe-ocenivanie-na-urokah-60079.html

15 [Электронный pecypc]. Режим доступа: http://collegy.ucoz.ru/load/5-1-0-2882

16 Кристиан В. Интерактивные учебные материалы на основе физлетов / В. Кристиан, М. Беллони // Компьютерные инструменты в образовании. - СПб.: Информатизация образования, 2003. — № 5. — С. 30. 


\title{
Л.Ф. Ильина, А.А. Харисова \\ «Механикалық тербелістер мен толқындар» бөлімінің мысалында мультимедиалық презентацияларды әзірлеу және оларды мектеп қабырғасында және жоғарғы оку орнында қолдану
}

\begin{abstract}
Физикадан сабақ беру барысында, басқа да оқу пәндері сияқты, түрлі оқыту әдісі қолданылуы тиіс. Кез келген оқыту әдістерді таңдау барысында, ең алдымен, сабақтың оқу міндеттерінің сипаты және де жоғары сынып оқушылары мен студенттердің жас ерекшеліктері, олардың танымдық қабілеттерін және деңгейін ескеру қажет. Мақалада «Механикалық тербелістер мен толқындар» бөлімінің мысалында мультимедиалық тұсаукесер әзірлеу және оларды мектеп курсында, сондай-ақ жоғарғы оқу орнында пайдаланылуы қарастырылған. Теория мәселесі қысқаша талқыланды. Тербелмелі үрдістің кинематикалық және динамикалық талдауы ұсынылды. Жоғарғы оқу орнында физика бөлімінде осы тақырыптың мазмұнды ерекшелігі талданды. Мақаланың өзектілігі болып мәтіннің мазмұндық әдістемесін әзірлеуі, базалық, жалпы, кәсіптік білім беретін мектептерде әрі университеттегі физиканың жалпы бөлімінде қолданысқа енгізу табылады.
\end{abstract}

Кілт сөздер: механикалық тербелістер мен толқындар, гармоникалық тербелістер, физикалық және математикалық маятник.

\section{Л.Ф. Ильина, А.А. Харисова}

\section{Разработка мультимедийных презентаций на примере раздела «Механические колебания и волны» и их использование в вузовском и школьном курсах физики}

\begin{abstract}
В преподавании физики, как и в преподавании других учебных предметов, должны применяться разнообразные методы обучения. При выборе тех или иных методов обучения следует учитывать, прежде всего, характер решаемых на уроке учебных задач, возрастные особенности учащихся старших классов, студентов, их стремление к самостоятельным суждениям, уровень имеющихся у них познавательных умений. В статье рассмотрены мультимедийные презентации на примере раздела «Механические колебания и волны» и их использование в вузовском и школьном курсах физики. Актуальность статьи заключается в необходимости разработки методики изложения темы с тем, чтобы ее можно было использовать при реализации как базового, так и профильного образования в школе и в университете в курсе общей физики. Кратко изложена теория вопроса, а также представлен кинематический и динамический анализы колебательного процесса. Проанализированы особенности содержания данной темы в вузовском курсе физики.
\end{abstract}

Ключевые слова: механические колебания и волны, гармонические колебания, физический и математический маятник.

\section{References}

1 Bezrukova, V.S. (2004). Vse o sovremennom uroke $v$ shkole: problemy i resheniia [In total about a modern lesson at school: problems and decisions]. Moscow: Sentiabr. Corifei.

2 Grebenkina, T.M. (2005). Fizika. 7 klass. Nestandartnye uroki [Physic. 7 form. Non-standard lessons]. Volgograd: ITD

3 Mastropas, Z.P., \& Sindeev, Y.G. (2002). Fizika: Metodika i praktika prepodavaniia [Physic: Technique and practice of teaching]. Rostov on Don: Feniks.

4 Frish, S.E., \& Timoreva, A.V. (1962). Kurs obshchei fiziki. T. 1. Fizicheskie osnovy mekhaniki. Molekuliarnaia fizika. Kolebaniia $i$ volny [Course of the general physics. Volume 1. Physical bases of mechanics. Molecular physics. Fluctuations and waves]. Moscow: GIFML.

5 Obmorshev, A.N. (1965). Vvedenie v teoriiu kolebanii [Introduction to the theory of oscillations]. Moscow: Nauka.

6 Retreived from: http://eqworld.ipmnet.ru/ru/library.htm

7 Retreived from: http://flash-fizika.narod.ru/physic.doc.com

8 Aleksandrov, N.V., \& Yashkin A.Ya. (1978). Kurs obshchei fiziki. Mekhanika [Course of the general physics. Mechanic]. Moscow: Prosveshchenie.

9 Chernoutsan, A.I. (2002). Kratkii kurs fiziki [Short course of physics]. Moscow: Fizmatlit.

10 Orior, D. (1981). Fizika [Physic]. (Vol. 1). Moscow: Mir. 
11 Irodov, I.E. (1988). Zadachi po obshchei fizike [Tasks in the general physics]. Moscow: Nauka.

12 Stepanova, G.N. (1997). Sbornik voprosov i zadach po fizike. Dlia 10-11 klassov obshcheobrazovatelnoi shkoly [Collection of questions and tasks in physics. For 10-11 classes of comprehensive school]. Saint Petersburg: Spetsialnaia literatura.

13 Balash, V.A. (1974). Zadachi po fizike i metody ikh resheniia [Tasks in physics and methods of their decision]. Moscow: Prosveshchenie.

14 Retreived from: http://www.metod-kopilka.ru/formativnoe-ocenivanie-na-urokah-60079.html

15 Retreived from: http://collegy.ucoz.ru/load/5-1-0-2882

16 Christian, V., \& Belloni, M. (2003). Interaktivnye uchebnye materialy na osnove fizletov [Interactive training materials on the basis of fizlet]. Kompiuternye instrumenty v obrazovanii - Computer tools in education, Saint Petersburg: Informatizatsiia obrazovaniia, 5,30 . 